\title{
Genetics of premature ovarian insufficiency and the association with $\mathrm{X}$-autosome translocations
}

\author{
Adriana Di-Battista, Mariana Moysés-Oliveira and Maria Isabel Melaragno \\ Genetics Division, Department of Morphology and Genetics, Universidade Federal de São Paulo, São Paulo, Brazil \\ Correspondence should be addressed to M I Melaragno; Email: melaragno.maria@unifesp.br
}

\begin{abstract}
Premature ovarian insufficiency (POI) is the cessation of menstruation before the age of 40 and can result from different etiologies, including genetic, autoimmune, and iatrogenic. Of the genetic causes, single-gene mutations and cytogenetic alterations, such as X-chromosome aneuploidies and chromosome rearrangements, can be associated with POI. In this review, we summarize the genetic factors linked to POI and list the main candidate genes. We discuss the association of these genes with the ovarian development, the functional consequences of different mutational mechanisms and biological processes that are frequently disrupted during POI pathogenesis. Additionally, we focus on the high prevalence of X-autosome translocations involving the critical regions in Xq, known as POI1 and POI2, and discuss in depth the main hypotheses proposed to explain this association. Although the incorrect pairing of chromosomes during meiosis could lead to oocyte apoptosis, the reason for the prevalence of X-chromosome breakpoints at specific regions remains unclear. In most cases, studies on genes disrupted by balanced structural rearrangements cannot explain the ovarian failure. Thus, the position effect has emerged as a putative explanation for genetic mechanisms as translocations possibly result in changes in overall chromatin topology due to chromosome repositioning. Given the tremendous impact of POI on women's quality of life, we highlight the value of investigations in to the interplay between ovarian function and gene regulation to deepen our understanding of the molecular mechanisms related to this disease, with the ultimate goal of improving patients' care and assistance. Reproduction (2020) 160 R55-R64
\end{abstract}

\section{Premature ovarian insufficiency}

Premature ovarian failure (POF), or premature ovarian insufficiency (POI) in the updated nomenclature (Welt 2008), is a condition generated by the early depletion or non-functionality of the ovarian reserve (Fortuno \& Labarta 2014). It affects $1-2 \%$ of women younger than 40 years of age and $0.1 \%$ of women younger than 30 years (Coulam et al. 1986), leading to defects in the reproductive system and infertility in those patients.

POI manifestation may vary among individuals, presenting either with severe forms, such as absent pubertal development and primary amenorrhea, or milder forms with early post-pubertal onset with the disappearance of menstrual cycles (secondary amenorrhea) and defective folliculogenesis (Genesio et al. 2015). It is generally characterized by elevated gonadotropin levels, hypoestrogenism, and amenorrhea, showing menopausal levels of folliclestimulating hormone (FSH), estradiol, and anti-mullerian hormone (AMH) (Visser et al. 2012). The symptoms may include menopausal experience, with hot flushes, night sweats, and vaginal dryness, associated with the loss of fertility and an increased risk of osteoporosis (Nelson et al. 2009).
For many women with $\mathrm{POI}$, the treatment is based on symptom relief using exogenous steroids, with estrogen and progestin replacement therapy, starting as soon as diagnosed (De Vos et al. 2010). Some measures to protect against osteoporosis should be recommended for patients with estrogen deficient levels, including the increase of physical exercises and calcium and vitamin D rich diet, as well as avoiding risk factors, such as smoking and high alcohol intake (Drillich \& Davis 2007).

\section{POI etiology}

Among the main causes of POI are (1) iatrogenic factors, for example, pelvic surgery and chemotherapy, (2) environmental factors, for example, viral infections and toxins, (3) autoimmune diseases with anti-ovarian antibodies resulting in ovarian damage, and (4) genetic alterations, including point mutations and chromosome imbalances involving $X$ chromosome or autosomes (Goswami \& Conway 2007). Despite clinical advances, more than $50 \%$ of $\mathrm{POI}$ cases remain idiopathic (Persani et al. 2010), and can present with sporadic or familial forms (van Kasteren \& Schoemaker 1999). Genetic factors may be the cause, or simply predispose 
the individual to the disease. Regarding POI, those factors can be identified in approximately $20-25 \%$ of cases (Qin et al. 2015).

\section{Genetic studies and candidate genes}

The identification of causal genes related to $\mathrm{POI}$ in non-syndromic families can be challenging, since infertility is the main phenotype, usually resulting in absent informative family histories (Woad et al. 2006). Nonetheless, $\sim 10-15 \%$ of the cases have an affected first-degree relative, indicating significant genetic etiology (van Kasteren \& Schoemaker 1999), and population genetic studies have revealed pathogenic variants all over the genome (Fig. 1A and Table 1).

With the improvement of next-generation sequencing techniques, whole-exome sequencing (WES) aggregation studies have explored the role of rare damaging coding variants on the ovarian development and related phenotypes. Those studies have confirmed the involvement of a handful of long-standing POI candidate genes and pointed to novel variants in their coding sequence (Yatsenko \& Rajkovic 2019), with higher reliability. The rising of those unbiased approaches have also enabled the application of WES in non-syndromic $\mathrm{POI}$, pinpointing several genes not previously associated (Qin et al. 2015). Jolly et al. performed WES in 42 affected females with POI from 36 unrelated families and identified likely damaging variants in eight known genes and predicted deleterious variants in four genes not previously associated with POI (Jolly et al. 2019). Recently, additional studies performed WES in single $\mathrm{POI}$ pedigrees and identified variants in genes known to be associated with POI, such as SALL4, EIF4ENIF1, and HFM1, corroborating the relevance of this method as a powerful diagnostic tool (Wang et al. 2019, Zhao et al. 2019, Zhe et al. 2019).

Another useful method, genome-wide association study (GWAS) provides an agnostic search, with no a priori expectations, in which hundreds of thousands of common genetic variants are screened to assess their association with a trait. The variability of menopausal age has been evaluated by GWAS, providing additional information on the combined impact of identified variants to this specific trait (Stolk et al. 2012, Perry et al. 2013). In addition, even though most GWAS on cohorts of POI patients were conducted in small sample sizes, those efforts were able to pinpoint association or susceptibility of POI phenotype with eight genes and also regulatory regions (Corre et al. 2009, Qin et al. 2015).

The genetic architecture of POI is composed of rare damaging variants as well as common variants with smaller effect. In Table 1, it is possible to observe that these different mutational mechanisms can impact genes within similar biological pathways, leading to POI through diverse cellular processes that are related

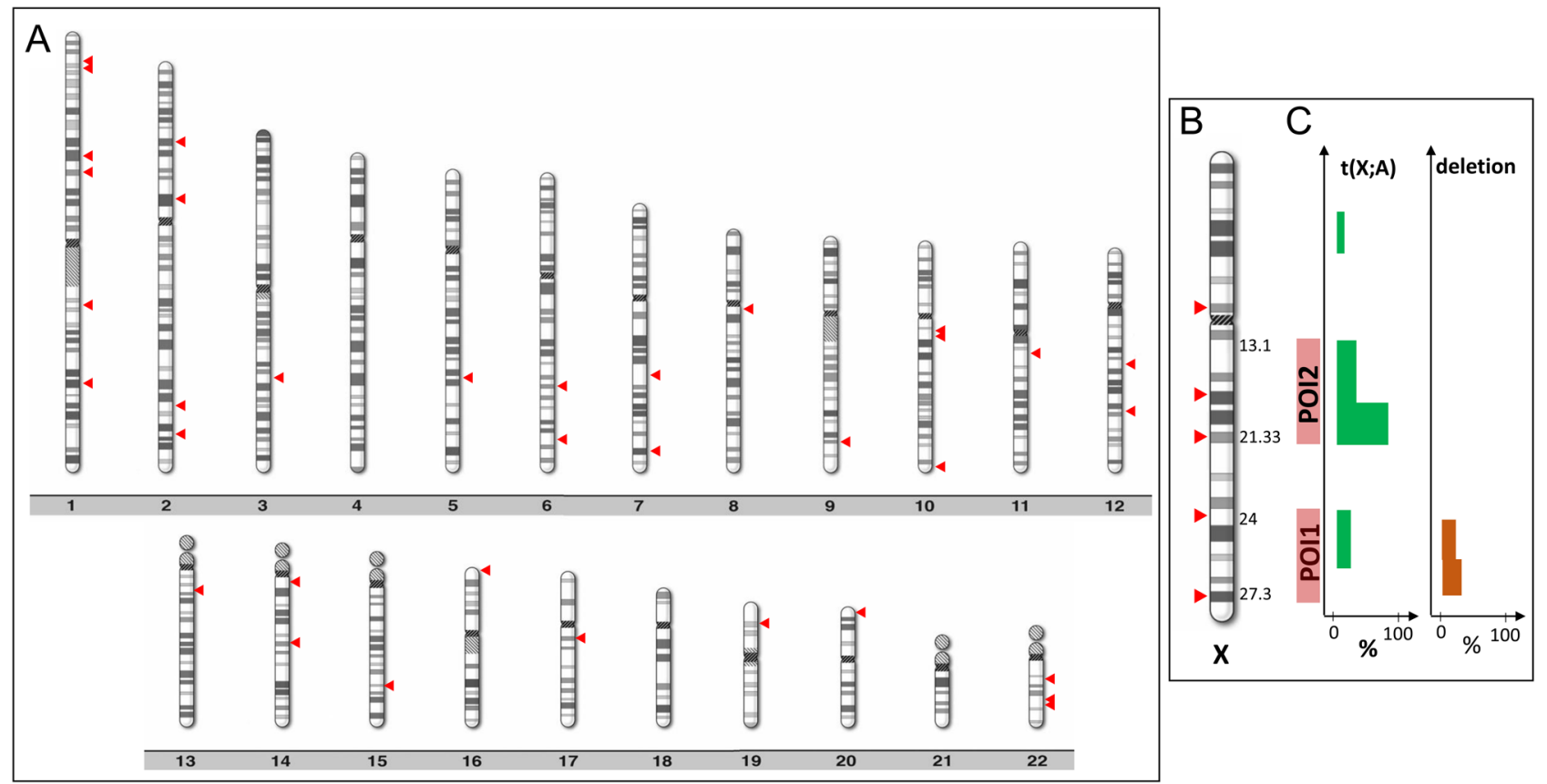

Figure 1 Schematic view of most relevant POl-associated genomic regions with candidate genes (further described in Table 1). (A) Genomic localization (red arrow) of autosomal candidate genes driven by point mutations. (B) Genomic localization (red arrow) of candidate genes in the chromosome X, driven by point mutations. (C) Genomic localization of POI1 and POI2, the X-linked genomic regions commonly affected by $\mathrm{POI}$-associated structural variants. On the right, the green and orange blocks schematically represent the approximate disruption frequency among POI-associated translocations and deletions, respectively, according to genomic location (Mumm et al. 2001, Portnoi et al. 2006, Rizzolio et al. 2006, Baronchelli et al. 2011). 
Table 1 Main biological pathways implicated in POI-associated genetic variants and most relevant candidate genes.

\begin{tabular}{|c|c|c|}
\hline Biological pathways/gene & $\begin{array}{l}\text { Study } \\
\text { type }\end{array}$ & References \\
\hline \multicolumn{3}{|c|}{ Transcription factor involved in sexual development } \\
\hline NR5A1 & WES & Eggers et al. (2015) \\
\hline WT1 & CGES & Wang et al. (2015) \\
\hline FOXL2 & WES & Yang et al. (2017) \\
\hline BMP15 & WES & Kumar et al. (2017) \\
\hline GDF9 & CGES & Kumar et al. (2017) \\
\hline FIGLA & WES & Tosh et al. (2015) \\
\hline NOBOX & WES & França et al. (2017) \\
\hline SALL4 & WES & Wang et al. (2019) \\
\hline \multicolumn{3}{|c|}{ Homologous recombination repair during meiosis } \\
\hline SYCE1 & WES & de Vries et al. (2014) \\
\hline SPIDR & WES & Smirin-Yosef et al. (2017) \\
\hline PSMC $3 I P$ & WES & Zangen et al. (2011) \\
\hline \multicolumn{3}{|l|}{ DNA mismatch repair } \\
\hline $\mathrm{MSH} 4$ & WES & Carlosama et al. (2017) \\
\hline MSH5 & WES & Guo et al. (2017) \\
\hline ERCC6 & WES & Qin et al. (2015) \\
\hline EXO1 & GWAS & Stolk et al. (2012) \\
\hline UIMC1 & GWAS & Stolk et al. (2012) \\
\hline \multicolumn{3}{|c|}{ Double strand break repair } \\
\hline MCM8 & WES & AlAsiri et al. (2015) \\
\hline MCM9 & WES & Wood-Trageser et al. (2014) \\
\hline FANCI & GWAS & Stolk et al. (2012) \\
\hline HELQ & GWAS & Stolk et al. (2012) \\
\hline \multicolumn{3}{|l|}{ DNA replication } \\
\hline PRIM1 & GWAS & Stolk et al. (2012) \\
\hline$T L K 1$ & GWAS & Stolk et al. (2012) \\
\hline POLG & GWAS & Stolk et al. (2012) \\
\hline HFM1 & WES & Zhe et al. (2019) \\
\hline \multicolumn{3}{|c|}{ mRNA transport and translation } \\
\hline FMR1 & CGS & Dean et al. (2018) \\
\hline STAG3 & WES & Caburet et al. (2014) \\
\hline KHDRBS1 & WES & Wang et al. (2017) \\
\hline NUP107 & WES & Weinberg-Shukron et al. (2015) \\
\hline \multicolumn{3}{|l|}{ Germ cell development } \\
\hline NANOS3 & CGES & Santos et al. (2014) \\
\hline elF4ENIF1 & WES & Zhao et al. (2019) \\
\hline SOHLH1 & WES & Jolly et al. (2019) \\
\hline \multicolumn{3}{|c|}{ Sexual hormone pathway } \\
\hline PGRMC1 & CGES & Mansouri et al. (2008) \\
\hline$A M H$ & WES & Qin et al. (2014a) \\
\hline AMHR2 & WES & Qin et al. (2014a) \\
\hline FSHR & WES & Bramble et al. (2016) \\
\hline \multicolumn{3}{|l|}{ Immune pathway } \\
\hline IL11 & GWAS & Stolk et al. (2012) \\
\hline NLRP11 & GWAS & Stolk et al. (2012) \\
\hline$P R R C 2 A$ & GWAS & Stolk et al. (2012) \\
\hline
\end{tabular}

CGES, candidate gene exon sequencing; CGS, candidate gene sequencing.

to ovarian development and oogenesis. Since oogenesis is a process that involves a complex interaction between the oocyte and somatic surrounding cells, it calls for a fine orchestration of multiple transcriptional regulators (Pangas et al. 2006). The combination of the most relevant and consistent results leveraged by genetic studies pointed to several causative mutations in transcription factors, which are currently considered as the most reliable candidate genes for POI (Qin et al. 2014b).
In this scenario, genetic screenings have proven to be useful to identify potentially causative genes based on their role in folliculogenesis and ovarian function (Qin et al. 2012). A number of studies have used in vitro cellular modeling to demonstrate that some of the rare genomic variants associated with $\mathrm{POI}$ indeed cause functional impairments in their correspondent mutated proteins, as shown for WT1, NR5A1, FSHR, NANOS3, and BMP15 (Santos et al. 2014, Wang et al. 2015, Liu et al. 2017, Robevska et al. 2018). An interesting example is a study performed by Wang et al. which assayed in vitro two WT1 missense variants and showed that they modulated the expression of downstream genes required for granular cells proliferation, differentiation and interaction with oocytes, suggesting WT1 gene variants as plausible causes for POI (Wang et al. 2015).

However, few studies have directly accessed the association between $\mathrm{POI}$-associated genes and the ovarian function and/or development. Transcription and growth factors were preferentially screened (NOBOX, FIGLA, WT1, and FOXL2) in functional studies, which are represented in Fig. 2A. These studies were performed mainly two types of experiments: (1) gene suppression (by knockout or knockdown) in animal models and (2) patients' gene variants knockin in animal models or gonadal in vitro cellular systems, in which the impact in ovarian development was assessed (Dong et al. 1996, Lechowska et al. 2011, Gao et al. 2014, Qin et al. 2018).

Theepistasis interaction between differenttranscription factors associated with POI has also been investigated (Fig. 2B). Some studies have demonstrated that variants found in $N O B O X$ in $\mathrm{POI}$ patients had an impact in the expression of GDF9, a growth differentiation factor gene, whose role in oocyte differentiation is well established. Similarly, an indel mutation identified in FOXL2 impaired its function, preventing it to activate StAR promoter, a steroidogenic regulatory protein essential for follicle development. (Bouilly et al. 2011, Chai et al. 2017, Li et al. 2017, Men et al. 2017). In early functional studies, StAR was demonstrated to be restricted to most steroidogenic compartments of the human ovary, thecal and luteinized granulosa cells, which was shown to be particularly relevant for the production of large amounts of progesterone (Kiriakidou et al. 1996).

Functional studies have provided significant advances in the understanding of ovarian development and follicle maturation, especially related to their gene regulatory pathways, emphasized by the frequent involvement of transcription factors. Further research will be crucial to address the significance of these findings in human POI pathogenesis, assessing the fine regulation of physiological functioning in the reproductive system. $\mathrm{POI}$-associated genes from other functional classes, for example, DNA replication and repair, remain to be investigated in functional assays of the ovarian development and will require further attention in future studies in the field. 


\section{$\mathrm{X}$ chromosome abnormalities}

Among the genetic causes of $\mathrm{POI}, \mathrm{X}$ chromosome numerical and structural alterations are the commonest imbalances, representing about $13 \%$ of the cases (Cordts et al. 2011). POI involving $X$ chromosomal abnormalities includes $\mathrm{X}$ monosomy or trisomy, $\mathrm{X}$ chromosome partial deletions, isochromosomes, inversions, and balanced X-autosomal translocations (Sala et al. 1997, Sherman 2000, Goswami \& Conway 2005, Moyses-Oliveira et al. 2015), showing the importance of karyotype and cytogenomic evaluation in patients with ovarian dysgenesis.
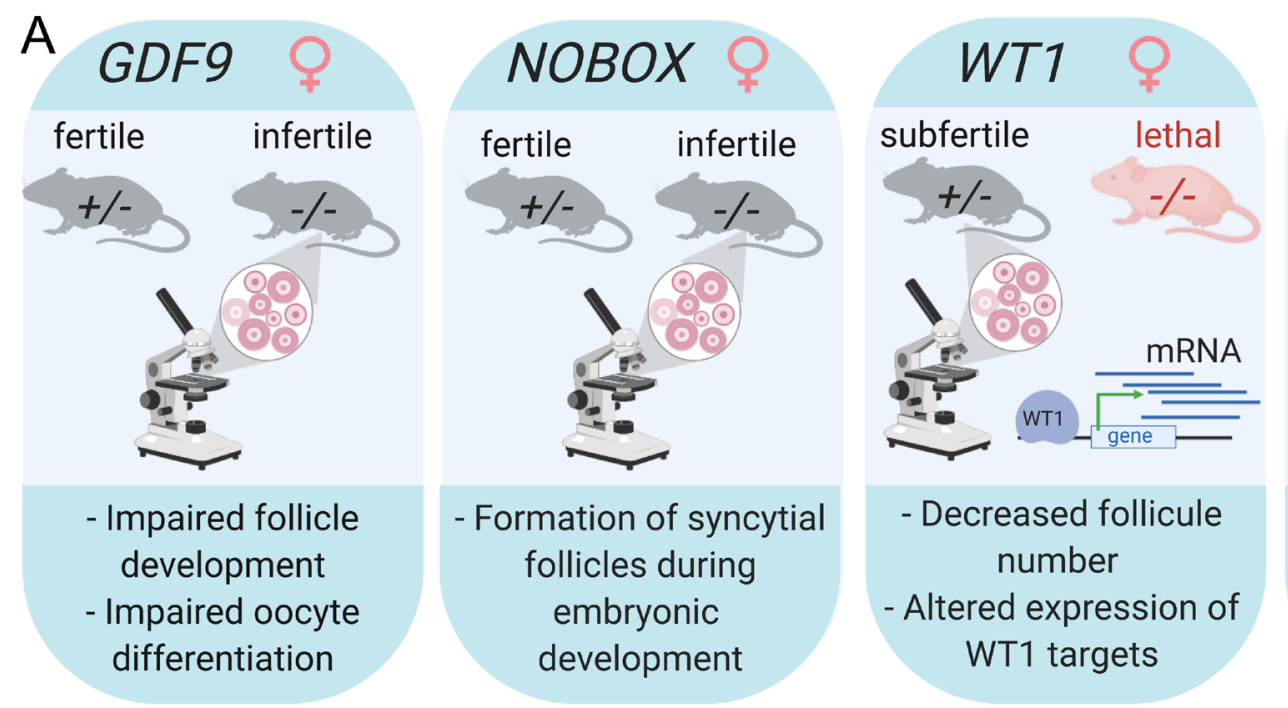

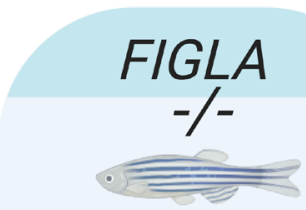

"all-male" development

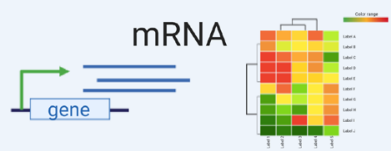

- Transcriptome-wide analysis: disruption of oogenesis pathways

B
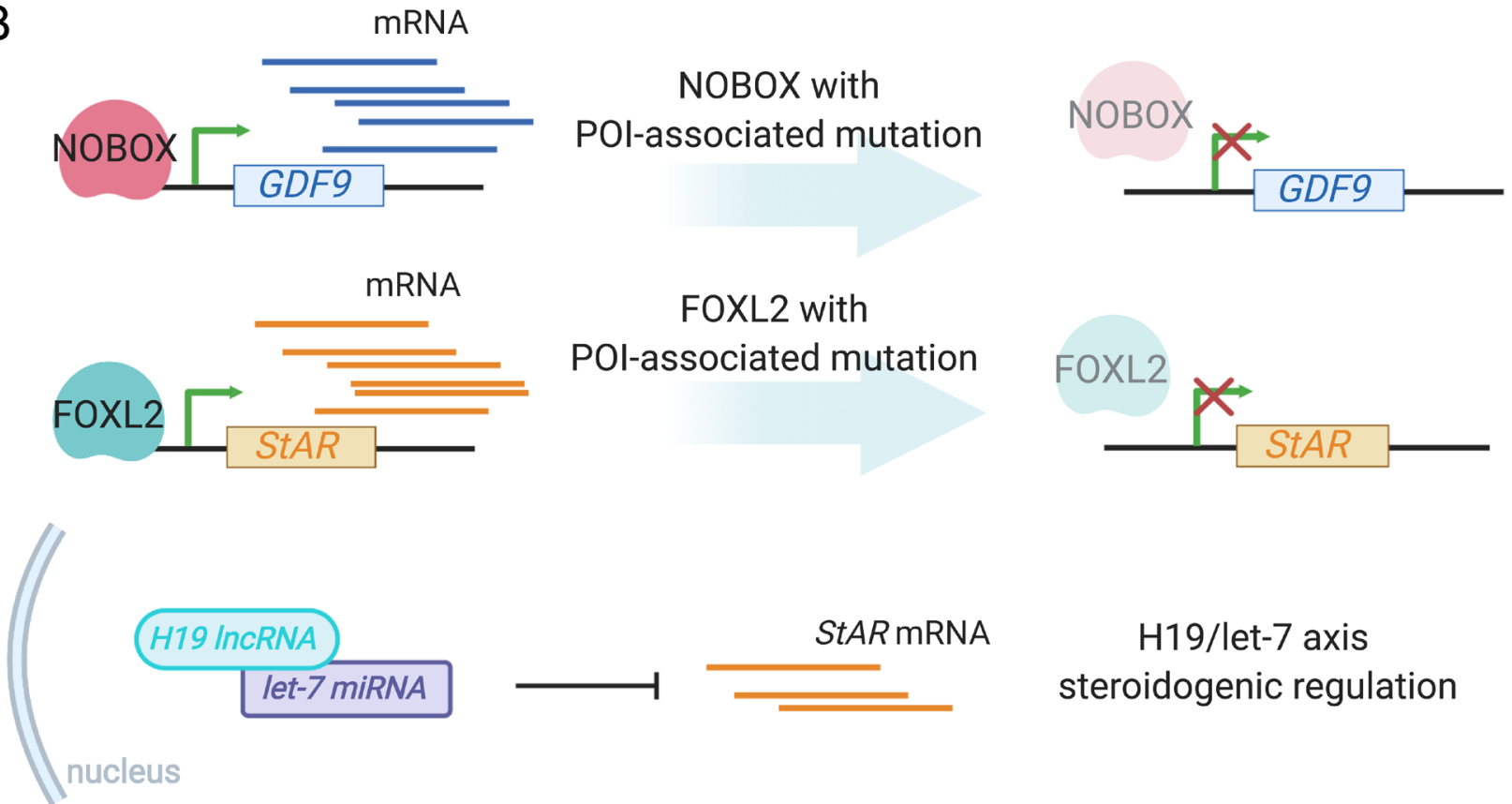

Figure 2 Functional studies indicate the importance of transcription factors for ovarian development. (A) Ovarian histological analysis of GDF9 and NOBOX mutant mice showed defects in follicle development, leading to infertility (Dong et al. 1996, Lechowska et al. 2011). While WT1 homozygous mice were not viable, heterozygous female mice presented with decreased follicle number and altered expression of WT1 gene targets, resulting in a subfertility of $\sim 15 \%$ (Gao et al. 2014). FIGLA knockout in zebrafish resulted in 'all-male' development, in which an estrogen treatment failed to rescue the phenotype. Transcriptome-wide analysis demonstrated an altered regulation of pathways related to oocyte development (Qin et al. 2018). (B) Mutations in NOBOX and FOXL2 impact their transcription factor activity, preventing them to bind at target genes, essential for follicle development (Bouilly et al. 2011, Chai et al. 2017, Li et al. 2017). Steroidogenesis is regulated by H19/let-7 axis by activating StAR expression (Men et al. 2017). 
Among the aneuploidies, Turner syndrome (X monosomy) has an incidence of 1:2500 and is associated with short stature, gonadal dysgenesis, and primary amenorrhea (Hook \& Warburton 2014). Even though most women with Turner syndrome are infertile due to gonadal dysgenesis, a minority of these patients reach menarche, most of them with the monosomy in mosaic $(45, X / 46, X X)$, which can present ovaries with a relatively low number of follicles (Abir et al. 2001).

Another frequently observed $X$ chromosome aneuploidy is the trisomy $X(47, X X X)$, which occurs in approximately $1: 1000$ females, but only $10 \%$ of the cases are diagnosed (Cordts et al. 2011). In trisomy $X$, pubertal onset and sexual development usually follow the typical trajectory; however, there are several reports of patients presenting with POI characterized by endocrine findings of hypergonadotropic hypogonadism (Villanueva \& Rebar 1983).

Regarding the structural rearrangements involving the $X$ chromosome, the isochromosome $(46, X, i(X)(q 10))$ is frequently observed, with most patients presenting with Turner syndrome phenotype, indistinct of the $45, X$ patients. Deletions and translocations have also been described in $\mathrm{POI}$, and show enrichment for breakpoints within the long arm of the X chromosome (Rizzolio et al. 2006). Deletions usually present breakpoints in the Xq24Xq27 region (Powell et al. 1994, Eggermann et al. 2005), while translocation breakpoints occur predominantly from Xq13 to Xq21 (Powell et al. 1994, Davison et al. 2000). Based on these observations, the $X q 24-q 27$

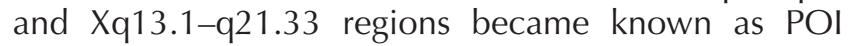
critical regions 1 and 2, respectively (Summitt et al. 1978) (Fig. 1C).

\section{POI and X-autosome translocations}

POI patients represent an important group among $\mathrm{X}$-autosome translocation carriers, independently of which autosome is involved in the rearrangement. POI is observed in approximately $50 \%$ of translocations affecting the $X$ chromosome (Therman et al. 1990). It is important to mention that the breakpoints usually fall in one of the two POI critical regions, while breakpoints outside these regions rarely result in ovarian development impairment (Mumm et al. 2001).

Encompassed by POI2 region, the chromosome band $\mathrm{Xq} 21$ concentrates around $80 \%$ of the breakpoints (Portnoi et al. 2006, Rizzolio et al. 2006) (Fig. 1C). Interestingly, interstitial deletions of this region do not seem to affect ovarian function (Cremers et al. 1989, Aboura et al. 2009), suggesting that this phenotype might not be related to the loss of the $\mathrm{Xq} 21$ region. In addition to the fact that $\mathrm{Xq} 21$ monosomy is not associated with ovarian phenotypes, this chromosomal segment is identified as a gene-poor region (Rizzolio et al. 2006). Thus, the main hypotheses proposed to explain the relationship between balanced X-autosome translocations and $\mathrm{POI}$ are related to gene disruption, meiosis error, and/or position effect.

\section{Gene disruption hypothesis}

In this first hypothesis regarding the association of POI with $\mathrm{X}$-autosome translocation, it has been proposed that a group of genes at the critical regions would be involved in ovarian function, leading to gonadal dysgenesis (Davison et al. 2000). However, only a few X-linked genes were pointed as a candidate for POI (Fig. 1B), and in some patients, Mumm et al. found the breakpoints in the X-autosome translocations located in regions with no genes (Mumm et al. 2001).

Similarly, Moysés-Oliveira et al. determined the breakpoint of three patients with $\mathrm{X}$-autosome translocations and $\mathrm{POI}$, all of them with $\mathrm{X}$ chromosome breakpoint at $\mathrm{POI} 2$, but with no gene disruptions capable of explaining their ovarian dysgenesis (MoysesOliveira et al. 2015). Genesio et al. described one patient with a balanced translocation between Xq21 (POI2 region) and $1 \mathrm{q} 41$, presenting short stature and $\mathrm{POI}$ in whom no gene disruptions were identified but gene expression alterations of ovarian related genes were observed (Genesio et al. 2015).

Although most of the breakpoints in $\mathrm{Xq} 21$ have been mapped to gene-free genomic regions, two genes (POF1B and DACH2) were screened to mutations in over 200 patients with POI (Bione et al. 2004). Rare mutations were found for both genes; however, the genetic analysis failed to show association with POF1B and suggested that $\mathrm{DACH} 2$ might be related to the $\mathrm{POI}$ phenotype, proposing that further investigation should be necessary to elucidate this association.

These findings, similar to others, reinforce that more complex mechanisms should be involved in POI associated with X-autosome translocations (Toniolo \& Rizzolio 2007).

\section{Meiosis error hypothesis}

It has been shown that some $X$ chromosomal imbalances result in increased oocyte atresia since, after meiosis initiation, both $\mathrm{X}$ chromosomes are active in germ cells. The loss of one $X$ chromosome constitutes true monosomy in these cells, and indeed, ovarian dysgenesis is one of the main symptoms in Turner syndrome (Therman et al. 1990). During the development of Turner syndrome fetuses, normal ovaries development and primordial germ cells are observed up to the third month of gestation, followed by a cellular apoptosis process resulting in gonadal connective tissue devoid of follicles (Singh \& Carr 1966). The absence of one chromosome in Turner syndrome could also result in perturbations in telomere length and/or function, contributing to the association with $\mathrm{POI}$, since telomeres are essential for proper 
chromosomal pairing, and other early steps in meiosis and oogenesis (Jackson-Cook 2019).

Similarly, this hypothesis suggests that translocations, disrupting genes or not, could influence the $X$ chromosome dynamics during the formation and maintenance of ovarian follicles (Mumm et al. 2001). It has been proposed that the incorrect pairing of translocation-derived chromosomes could affect the checkpoints between meiosis phases in germ cells and lead to oocyte apoptosis (Schlessinger et al. 2002). It is important to consider the difficulty of properly addressing this matter, due to restriction of accessing target gonadal cells in the developing ovary, combined with the challenge of modeling cellular states with both $\mathrm{X}$ chromosomes in the active state, especially during gonadal development.

Additionally, such suggestions do not consider the enrichment for translocations in the POI critical regions. Although $\mathrm{Xp}$ and $\mathrm{Xq}$ deletion carriers can present both normal and deficient ovarian development, a higher percentage of $\mathrm{Xq}$ deletion carriers shows gonadal abnormalities, suggesting a more complex level of organization related to gonadal development in this chromosome.

\section{Position effect hypothesis}

The position effect hypothesis refers to changes in the overall chromatin topology due to chromosome repositioning after the translocation. Chromosome positioning during interphase is not random (Lanctot et al. 2007) and chromatin is organized in chromosome territories, or nuclear domains (Cremer et al. 2006). Genomic architecture is built upon physical interaction networks between different DNA segments (Miele \& Dekker 2008), thought to be essential for the correct genome regulation and biological functions of cells, such as transcription, replication, and DNA repair (Bonev \& Cavalli 2016).

The development of advanced chromatin conformation capture techniques, such as $\mathrm{Hi}-\mathrm{C}$ (Lieberman-Aiden et al. 2009, Belton et al. 2012), allowed the identification of an even more complex and well-defined three-dimensional organization, as known as topological-associated domains (TADs) (Dixon et al. 2012). Thus, chromosome rearrangements can lead to TAD disruptions and three-dimensional disorganization that can modify the interactions among regulatory elements and their target genes, possibly perturbing gene expression profiles (Zepeda-Mendoza et al. 2017, Despang et al. 2019, Finn \& Misteli 2019, GhaviHelm et al. 2019).

The occurrence of a reciprocal translocation could shift the derived chromosomes from their usual positions, perturbing specific cis- and trans-acting DNA regulatory elements and modifying the DNA accessibility in largescale (Harewood et al. 2010). It has been demonstrated that chromosomal breaks or deletions in gene-poor regions, like $\mathrm{Xq} 21$, could interfere with the functioning of genes localized far away from the breakpoint region since they could contain regulatory sequences (Nobrega et al. 2004). Therefore, POI due to X-autosome translocation could be related to the expression dysregulation of ovarian genes and not necessarily to the direct disruption of their sequence.

In males and females across species, only one $X$ chromosome is active, and a combination of upregulation and repression states was already observed during germline development, possibly to reach similar expression levels between $X$ chromosome genes and autosomal genes (Cheng \& Disteche 2006). This increased $\mathrm{X}$-chromosome expression in female and male cells was confirmed by single-cell RNA-seq, which indicated that the $\mathrm{X}$ chromosome achieved upregulation by elevated burst frequencies (Larsson et al. 2019). However, during female gametogenesis, the $\mathrm{POI} 2$ critical region presents a diminished gene expression in oocytes, which is not found elsewhere along the $X$ chromosome nor in the autosomes, downregulation probably due to an oocytespecific regulation (Rizzolio et al. 2007). In oocytes, since both $\mathrm{X}$ chromosomes are active, the upregulated state would not be necessary. Thus, it has been suggested that, in balanced X-autosome translocations, these epigenetic mechanisms responsible for diminishing the expression of the $\mathrm{Xq13}-\mathrm{q} 22$ region could be propagated to autosomal segments, conferring heterochromatic characteristics to this fragment (Rizzolio et al. 2009). Since there is no preferred autosomal partner in $t(X ; A)$ associated with ovarian phenotypes, this would implicate that many genes spread throughout the genome can be causative of $\mathrm{POI}$, and until now, the position effect mechanism related to POI2 region is not well defined. Nevertheless, POI candidate genes (Table 1) do not seem to be clustered in any specific genomic regions or chromosomes.

Since POI2 is thought to be a region poor in genes, but rich in regulatory elements, it is plausible to hypothesize that this region is essential for the correct functioning of genes related to ovarian development. The regulation of this critical region could be related to its spatial genome organization, which would be directly affected by the translocation breakpoint. Then, ovarian dysfunction due to $\mathrm{X}$-autosome translocations in $\mathrm{POI}$ would be the result of chromosomal segments shifting from their correct nuclear positioning regulatory alterations after a threedimensional shifting (Rizzolio et al. 2009).

It is worth to mention that the previously discussed hypotheses are not necessarily mutually exclusive; for instance, different kinds of rearrangements, even between autosomes, can result in $\mathrm{POI}$, pointing to meiosis error, or disruption of autosomal genes. In contrast, X-autosome translocations with breakpoints at the critical regions, that is, POI1 and POI2, are much more frequent, suggesting a high correlation of 
regulatory elements in this region with the phenotype. Additionally, most candidate genes for POI are not found in the critical regions as previously described.

\section{Conclusion}

The genetic factors underlying POI etiology are still poorly understood and seem to compose a complex pathogenic molecular mechanism. A wide range of biological processes (i.e. DNA replication and repair, mRNA transport and translation, germ cell development, sexual hormone pathways, and immune pathways) are frequently disrupted by common and rare genetic variation. Although animal modeling of $\mathrm{POI}$-associated transcription factors has been valuable for the field advancement, there is a vast list of genes with other biological roles that remain untouched by functional studies during the ovarian development. In a similar vein, chromosome rearrangements might disturb chromatin organization and result in consequences to phenotypic manifestations when this nuclear structure is perturbed. Since gene regulation is known to be causally linked to chromatin dynamics at interphasic nuclei, the investigation of the molecular pathways underlying the ovarian phenotype can represent a valuable resource to elucidate the regulatory control related to this precise organization.

We must consider that premature ovarian insufficiency is likely to be a multifactorial origin disorder that affects women's quality of life, which can often express depressive feelings, especially related to impaired fertility. For those women, infertility can be a significant issue, and although some of them might sporadically ovulate, this is not easily predictable. Considering the relatively high prevalence of $\mathrm{X}$-autosome translocations related to POI, we propose that further investigations of this group of patients should be conducted in order to identify the interplay between this phenotype, genomic structural variants, and the specific $X$ chromosome critical regions. This detailed screening can catalyze efforts to elucidate the disorder and possibly prevent some of the drawbacks for the patients, developing new diagnostic methods and better-targeted treatments.

\section{Declaration of interest}

The authors declare that there is no conflict of interest that could be perceived as prejudicing the impartiality of this review.

\section{Funding}

This work was supported by São Paulo Research Foundation (FAPESP) (grant 2014/11572-8 to M I M) and by the Coordenação de Aperfeiçoamento de Pessoal de Nível Superior - Brasil (CAPES).

\section{Author contribution statement}

Adriana Di-Battista performed the literature review and wrote the manuscript. Mariana Moysés-Oliveira and Maria Isabel Melaragno revised and edited the manuscript. Maria Isabel Melaragno was responsible for funding acquisition.

\section{References}

Abir R, Fisch B, Nahum R, Orvieto R, Nitke S \& Ben Rafael Z 2001 Turner's syndrome and fertility: current status and possible putative prospects. Human Reproduction Update 7 603-610. (https://doi.org/10.1093/ humupd/7.6.603)

Aboura A, Dupas C, Tachdjian G, Portnoi MF, Bourcigaux N, Dewailly D, Frydman R, Fauser B, Ronci-Chaix N, Donadille B et al. 2009 Array comparative genomic hybridization profiling analysis reveals deoxyribonucleic acid copy number variations associated with premature ovarian failure. Journal of Clinical Endocrinology and Metabolism 94 4540-4546. (https://doi.org/10.1210/jc.2009-0186)

Alasiri S, Basit S, Wood-Trageser MA, Yatsenko SA, Jeffries EP, Surti U, Ketterer DM, Afzal S, Ramzan K, Faiyaz-UI Haque M et al. 2015 Exome sequencing reveals MCM8 mutation underlies ovarian failure and chromosomal instability. Journal of Clinical Investigation 125 258-262. (https://doi.org/10.1172/JCl78473)

Baronchelli S, Conconi D, Panzeri E, Bentivegna A, Redaelli S, Lissoni S, Saccheri F, Villa N, Crosti F, Sala E et al. 2011 Cytogenetics of premature ovarian failure: an investigation on 269 affected women. Journal of Biomedicine and Biotechnology 2011 370195. (https://doi. org/10.1155/2011/370195)

Belton JM, Mccord RP, Gibcus JH, Naumova N, Zhan Y \& Dekker J 2012 Hi$\mathrm{C}$ : a comprehensive technique to capture the conformation of genomes. Methods 58 268-276. (https://doi.org/10.1016/j.ymeth.2012.05.001)

Bione S, Rizzolio F, Sala C, Ricotti R, Goegan M, Manzini M C, Battaglia R, Marozzi A, Vegetti W, Dalpra L et al. 2004. Mutation analysis of two candidate genes for premature ovarian failure, $\mathrm{DACH} 2$ and POF1B. Human Reproduction 19 2759-2766. (https://doi.org/10.1093/humrep/ deh502)

Bonev B \& Cavalli G 2016 Organization and function of the 3D genome. Nature Reviews: Genetics 17 661-678. (https://doi.org/10.1038/ nrg.2016.112)

Bouilly J, Bachelot A, Broutin I, Touraine P \& Binart N 2011 Novel NOBOX loss-of-function mutations account for $6.2 \%$ of cases in a large primary ovarian insufficiency cohort. Human Mutation 32 1108-1113. (https:// doi.org/10.1002/humu.21543)

Bramble MS, Goldstein EH, Lipson A, Ngun T, Eskin A, Gosschalk JE, Roach L, Vashist N, Barseghyan H, Lee E et al. 2016 A novel folliclestimulating hormone receptor mutation causing primary ovarian failure: a fertility application of whole exome sequencing. Human Reproduction 31 905-914. (https://doi.org/10.1093/humrep/dew025)

Caburet S, Arboleda VA, Llano E, Overbeek PA, Barbero JL, Oka K, Harrison W, Vaiman D, Ben-Neriah Z, García-Tuñón I et al. 2014 Mutant cohesin in premature ovarian failure. New England Journal of Medicine 370 943-949. (https://doi.org/10.1056/NEJMoa1309635)

Carlosama C, Elzaiat M, Patiño LC, Mateus HE, Veitia RA \& Laissue P 2017 A homozygous donor splice-site mutation in the meiotic gene $\mathrm{MSH} 4$ causes primary ovarian insufficiency. Human Molecular Genetics 26 3161-3166. (https://doi.org/10.1093/hmg/ddx199)

Chai P, Li F, Fan J, Jia R, Zhang H \& Fan X 2017 Functional analysis of a novel FOXL2 indel mutation in Chinese families with blepharophimosisptosis-epicanthus inversus syndrome Type I. International Journal of Biological Sciences 13 1019-1028. (https://doi.org/10.7150/ijbs.19532)

Cheng MK \& Disteche CM 2006 A balancing act between the $X$ chromosome and the autosomes. Journal of Biology 5 2. (https://doi. org/10.1186/jbiol32)

Cordts EB, Christofolini DM, Dos Santos AA, Bianco B \& Barbosa CP 2011 Genetic aspects of premature ovarian failure: a literature review. Archives of Gynecology and Obstetrics 283 635-643. (https://doi. org/10.1007/s00404-010-1815-4)

Corre T, Schuettler J, Bione S, Marozzi A, Persani L, Rossetti R, Torricelli F, Giotti I, Vogt P, Toniolo D et al. 2009 A large-scale association study to assess the impact of known variants of the human Inha gene on 
premature ovarian failure. Human Reproduction 24 2023-2028. (https:// doi.org/10.1093/humrep/dep090)

Coulam CB, Adamson SC \& Annegers JF 1986 Incidence of premature ovarian failure. Obstetrics and Gynecology 67 604-606. (https://doi. org/10.1097/00006254-198703000-00020)

Cremer T, Cremer M, Dietzel S, Muller S, Solovei I \& Fakan S 2006 Chromosome territories - a functional nuclear landscape. Current Opinion in Cell Biology 18 307-316. (https://doi.org/10.1016/j. ceb.2006.04.007)

Cremers FP, Van De Pol DJ, Diergaarde PJ, Wieringa B, Nussbaum RL, Schwartz M \& Ropers HH 1989 Physical fine mapping of the choroideremia locus using $\mathrm{Xq} 21$ deletions associated with complex syndromes. Genomics 4 41-46. (https://doi.org/10.1016/08887543(89)90312-1)

Davison RM, Fox M \& Conway GS 2000 Mapping of the POF1 locus and identification of putative genes for premature ovarian failure. Molecular Human Reproduction 6 314-318. (https://doi.org/10.1093/ molehr/6.4.314)

De Vos M, Devroey $\mathbf{P}$ \& Fauser BC 2010 Primary ovarian insufficiency. Lancet 376 911-921. (https://doi.org/10.1016/S01406736(10)60355-8)

De Vries L, Behar DM, Smirin-Yosef P, Lagovsky I, Tzur S \& BaselVanagaite L 2014 Exome sequencing reveals SYCE1 mutation associated with autosomal recessive primary ovarian insufficiency. Journal of Clinical Endocrinology and Metabolism 99 E2129-E2132. (https://doi. org/10.1210/jc.2014-1268)

Dean DD, Agarwal S, Kapoor D, Singh K \& Vati C 2018 Molecular characterization of FMR1 gene by TP-PCR in women of reproductive age and women with premature ovarian insufficiency. Molecular Diagnosis and Therapy 22 91-100. (https://doi.org/10.1007/s40291-017-0305-9)

Despang A, Schöpflin R, Franke M, Ali S, Jerković I, Paliou C, Chan WL, Timmermann B, Wittler L, Vingron M et al. 2019 Functional dissection of the Sox9-Kcnj2 locus identifies nonessential and instructive roles of TAD architecture. Nature Genetics 51 1263-1271. (https://doi.org/10.1038/ s41588-019-0466-z)

Dixon JR, Selvaraj S, Yue F, Kim A, Li Y, Shen Y, Hu M, Liu JS \& Ren B 2012 Topological domains in mammalian genomes identified by analysis of chromatin interactions. Nature 485 376-380. (https://doi.org/10.1038/ nature11082)

Dong J, Albertini DF, Nishimori K, Kumar TR, Lu N \& Matzuk MM 1996 Growth differentiation factor-9 is required during early ovarian folliculogenesis. Nature 383 531-535. (https://doi. org/10.1038/383531a0)

Drillich A \& Davis SR 2007 Androgen therapy in women: what we think we know. Experimental Gerontology 42 457-462. (https://doi.org/10.1016/j. exger.2007.02.005)

Eggermann T, Meschede D, Schuler H, Palm S, Glaser D, Horsthemke B, Eggermann K, Haverkamp F \& Zerres K 2005 Premature ovarian failure associated with a small terminal Xq deletion: narrowing the POF1 region down to Xq27.2/Xq27.3-qter. Clinical Genetics 67 434-437. (https://doi. org/10.1111/j.1399-0004.2005.00427.x)

Eggers S, Smith KR, Bahlo M, Looijenga LHJ, Drop SLS, Juniarto ZA, Harley VR, Koopman P, Faradz SMH \& Sinclair AH 2015 Whole exome sequencing combined with linkage analysis identifies a novel $3 \mathrm{bp}$ deletion in NR5A1. European Journal of Human Genetics 23 486-493. (https://doi.org/10.1038/ejhg.2014.130)

Finn EH \& Misteli T 2019 Molecular basis and biological function of variability in spatial genome organization. Science 365 eaaw9498. (https://doi.org/10.1126/science.aaw9498)

Fortuno C \& Labarta E 2014 Genetics of primary ovarian insufficiency: a review. Journal of Assisted Reproduction and Genetics 31 1573-1585. (https://doi.org/10.1007/s10815-014-0342-9)

França MM, Funari MFA, Lerario AM, Nishi MY, Pita CC, Fontenele EGP \& Mendonca BB 2017 A novel homozygous 1-bp deletion in the NOBOX gene in two Brazilian sisters with primary ovarian failure. Endocrine 58 442-447. (https://doi.org/10.1007/s12020-017-1459-2)

Gao F, Zhang J, Wang X, Yang J, Chen D, Huff V \& Liu YX 2014 Wt1 functions in ovarian follicle development by regulating granulosa cell differentiation. Human Molecular Genetics 23 333-341. (https://doi. org/10.1093/hmg/ddt423)

Genesio R, Mormile A, Licenziati MR, De Brasi D, Leone G, Balzano S, Izzo A, Bonfiglio F, Conti A, Fioretti G et al. 2015 Short stature and primary ovarian insufficiency possibly due to chromosomal position effect in a balanced $\mathrm{X} ; 1$ translocation. Molecular Cytogenetics 850 . (https://doi.org/10.1186/s13039-015-0154-3)

Ghavi-Helm Y, Jankowski A, Meiers S, Viales RR, Korbel JO \& Furlong EEM 2019 Highly rearranged chromosomes reveal uncoupling between genome topology and gene expression. Nature Genetics 51 1272-1282. (https://doi.org/10.1038/s41588-019-0462-3)

Goswami D \& Conway GS 2005 Premature ovarian failure. Human Reproduction Update 11 391-410. (https://doi.org/10.1093/humupd/ dmi012)

Goswami D \& Conway GS 2007 Premature ovarian failure. Hormone Research 68 196-202. (https://doi.org/10.1159/000102537)

Guo T, Zhao S, Zhao S, Chen M, Li G, Jiao X, Wang Z, Zhao Y, Qin Y, Gao F et al. 2017 Mutations in MSH5 in primary ovarian insufficiency. Human Molecular Genetics 26 1452-1457. (https://doi.org/10.1093/ $\mathrm{hmg} / \mathrm{ddx} 044)$

Harewood L, Schutz F, Boyle S, Perry P, Delorenzi M, Bickmore WA \& Reymond A 2010 The effect of translocation-induced nuclear reorganization on gene expression. Genome Research 20 554-564. (https://doi.org/10.1101/gr.103622.109)

Hook EB \& Warburton D 2014 Turner syndrome revisited: review of new data supports the hypothesis that all viable $45, X$ cases are cryptic mosaics with a rescue cell line, implying an origin by mitotic loss. Human Genetics 133 417-424. (https://doi.org/10.1007/s00439-0141420-x)

Jackson-Cook C 2019 A hypothesis: could telomere length and/ or epigenetic alterations contribute to infertility in females with Turner syndrome? American Journal of Medical Genetics: Part C, Seminars in Medical Genetics 181 108-116. (https://doi.org/10.1002/ ajmg.c.31684)

Jolly A, Bayram Y, Turan S, Aycan Z, Tos T, Abali ZY, Hacihamdioglu B, Coban Akdemir ZH, Hijazi H, Bas S et al. 2019 Exome sequencing of a primary ovarian insufficiency cohort reveals common molecular etiologies for a spectrum of disease. Journal of Clinical Endocrinology and Metabolism 104 3049-3067. (https://doi.org/10.1210/jc.201900248)

Kiriakidou M, Mcallister JM, Sugawara T \& Strauss 3rd JF 1996 Expression of steroidogenic acute regulatory protein (StAR) in the human ovary. Journal of Clinical Endocrinology and Metabolism 81 4122-4128. (https://doi.org/10.1210/jcem.81.11.8923870)

Kumar R, Alwani M, Kosta S, Kaur R \& Agarwal S 2017 BMP15 and GDF9 gene mutations in premature ovarian failure. Journal of Reproduction and Infertility 18 185-189.

Lanctot C, Cheutin T, Cremer M, Cavalli G \& Cremer T 2007 Dynamic genome architecture in the nuclear space: regulation of gene expression in three dimensions. Nature Reviews: Genetics 8 104-115. (https://doi. org/10.1038/nrg2041)

Larsson AJM, Coucoravas C, Sandberg R \& Reinius B 2019 X-chromosome upregulation is driven by increased burst frequency. Nature Structural and Molecular Biology 26 963-969. (https://doi.org/10.1038/s41594019-0306-y)

Lechowska A, Bilinski S, Choi Y, Shin Y, Kloc M \& Rajkovic A 2011 Premature ovarian failure in nobox-deficient mice is caused by defects in somatic cell invasion and germ cell cyst breakdown. Journal of Assisted Reproduction and Genetics 28 583-589. (https://doi.org/10.1007/ s10815-011-9553-5)

Li L, Wang B, Zhang W, Chen B, Luo M, Wang J, Wang X, Cao Y \& Kee K 2017 A homozygous NOBOX truncating variant causes defective transcriptional activation and leads to primary ovarian insufficiency. Human Reproduction 32 248-255. (https://doi.org/10.1093/humrep/ dew271)

Lieberman-Aiden E, Van Berkum NL, Williams L, Imakaev M, Ragoczy T, Telling A, Amit I, Lajoie BR, Sabo PJ, Dorschner MO et al. 2009 Comprehensive mapping of long-range interactions reveals folding principles of the human genome. Science 326 289-293. (https://doi. org/10.1126/science.1181369)

Liu H, Xu X, Han T, Yan L, Cheng L, Qin Y, Liu W, Zhao S \& Chen ZJ 2017 A novel homozygous mutation in the FSHR gene is causative for primary ovarian insufficiency. Fertility and Sterility 108 1050.e2-1055. e2. (https://doi.org/10.1016/j.fertnstert.2017.09.010)

Mansouri MR, Schuster J, Badhai J, Stattin EL, Lösel R, Wehling M, Carlsson B, Hovatta O, Karlström PO, Golovleva I et al. 2008 Alterations 
in the expression, structure and function of progesterone receptor membrane component-1 (PGRMC1) in premature ovarian failure. Human Molecular Genetics 17 3776-3783. (https://doi.org/10.1093/ hmg/ddn274)

Men Y, Fan Y, Shen Y, Lu L \& Kallen AN 2017 The steroidogenic acute regulatory protein (StAR) is regulated by the H19/let-7 axis. Endocrinology 158 402-409. (https://doi.org/10.1210/en.2016-1340)

Miele A \& Dekker J 2008 Long-range chromosomal interactions and gene regulation. Molecular Biosystems 4 1046-1057. (https://doi.org/10.1039/ b803580f)

Moyses-Oliveira M, Guilherme Rdos S, Dantas AG, Ueta R, Perez AB, Haidar M, Canonaco R, Meloni VA, Kosyakova N, Liehr T et al. 2015 Genetic mechanisms leading to primary amenorrhea in balanced $\mathrm{X}$-autosome translocations. Fertility and Sterility 103 1289.e2-1296.e2. (https://doi.org/10.1016/j.fertnstert.2015.01.030)

Mumm S, Herrera L, Waeltz PW, Scardovi A, Nagaraja R, Esposito T, Schlessinger D, Rocchi M \& Forabosco A 2001 X/autosomal translocations in the $\mathrm{Xq}$ critical region associated with premature ovarian failure fall within and outside genes. Genomics 76 30-36. (https://doi. org/10.1006/geno.2001.6611)

Nelson ML, Blum JM, Hollis BW, Rosen C \& Sullivan SS 2009 Supplements of $20 \mathrm{microg} / \mathrm{d}$ cholecalciferol optimized serum 25-hydroxyvitamin D concentrations in $80 \%$ of premenopausal women in winter. Journal of Nutrition 139 540-546. (https://doi.org/10.3945/jn.108.096180)

Nobrega MA, Zhu Y, Plajzer-Frick I, Afzal V \& Rubin EM 2004 Megabase deletions of gene deserts result in viable mice. Nature 431 988-993. (https://doi.org/10.1038/nature03022)

Pangas SA, Choi Y, Ballow DJ, Zhao Y, Westphal H, Matzuk MM \& Rajkovic A 2006 Oogenesis requires germ cell-specific transcriptional regulators Sohlh1 and Lhx8. PNAS 103 8090-8095. (https://doi. org/10.1073/pnas.0601083103)

Perry JR, Corre T, Esko T, Chasman DI, Fischer K, Franceschini N, He C, Kutalik Z, Mangino M, Rose LM et al. 2013 A genome-wide association study of early menopause and the combined impact of identified variants. Human Molecular Genetics 22 1465-1472. (https://doi.org/10.1093/ hmg/dds551)

Persani L, Rossetti R \& Cacciatore C 2010 Genes involved in human premature ovarian failure. Journal of Molecular Endocrinology 45 257-279. (https://doi.org/10.1677/JME-10-0070)

Portnoi MF, Aboura A, Tachdjian G, Bouchard P, Dewailly D, Bourcigaux N, Frydman R, Reyss AC, Brisset S \& Christin-Maitre S 2006 Molecular cytogenetic studies of $\mathrm{Xq}$ critical regions in premature ovarian failure patients. Human Reproduction 21 2329-2334. (https://doi.org/10.1093/ humrep/del174)

Powell CM, Taggart RT, Drumheller TC, Wangsa D, Qian C, Nelson LM \& White BJ 1994 Molecular and cytogenetic studies of an X;autosome translocation in a patient with premature ovarian failure and review of the literature. American Journal of Medical Genetics 52 19-26. (https:// doi.org/10.1002/ajmg.1320520105)

Qin Y, Sun M, You L, Wei D, Sun J, Liang X, Zhang B, Jiang H, Xu J \& Chen ZJ 2012 ESR1, HK3 and BRSK1 gene variants are associated with both age at natural menopause and premature ovarian failure. Orphanet Journal of Rare Diseases 7 5. (https://doi.org/10.1186/1750-1172-7-5)

Qin C, Yuan Z, Yao J, Zhu W, Wu W \& Xie J 2014a AMH and AMHR2 genetic variants in Chinese women with primary ovarian insufficiency and normal age at natural menopause. Reproductive Biomedicine Online 29 311-318. (https://doi.org/10.1016/j.rbmo.2014.05.003)

Qin Y, Jiao X, Dalgleish R, Vujovic S, Li J, Simpson JL, Al-Azzawi F \& Chen ZJ 2014b Novel variants in the SOHLH2 gene are implicated in human premature ovarian failure. Fertility and Sterility 101 1104.e61109.e6. (https://doi.org/10.1016/j.fertnstert.2014.01.001)

Qin Y, Jiao X, Simpson JL \& Chen ZJ 2015 Genetics of primary ovarian insufficiency: new developments and opportunities. Human Reproduction Update 21 787-808. (https://doi.org/10.1093/humupd/ dmv036)

Qin M, Zhang Z, Song W, Wong QW, Chen W, Shirgaonkar N \& Ge W 2018 Roles of Figla/figla in juvenile ovary development and follicle formation during zebrafish gonadogenesis. Endocrinology 159 3699-3722. (https://doi.org/10.1210/en.2018-00648)

Rizzolio F, Bione S, Sala C, Goegan M, Gentile M, Gregato G, Rossi E, Pramparo T, Zuffardi O \& Toniolo D 2006 Chromosomal rearrangements in $\mathrm{Xq}$ and premature ovarian failure: mapping of 25 new cases and review of the literature. Human Reproduction 21 1477-1483. (https:// doi.org/10.1093/humrep/dei495)

Rizzolio F, Sala C, Alboresi S, Bione S, Gilli S, Goegan M, Pramparo T, Zuffardi O \& Toniolo D 2007 Epigenetic control of the critical region for premature ovarian failure on autosomal genes translocated to the $X$ chromosome: a hypothesis. Human Genetics 121 441-450. (https://doi. org/10.1007/s00439-007-0329-z)

Rizzolio F, Pramparo T, Sala C, Zuffardi O, De Santis L, Rabellotti E, Calzi F, Fusi F, Bellazzi R \& Toniolo D 2009 Epigenetic analysis of the critical region I for premature ovarian failure: demonstration of a highly heterochromatic domain on the long arm of the mammalian $X$ chromosome. Journal of Medical Genetics 46 585-592. (https://doi. org/10.1136/jmg.2007.056093)

Robevska G, Van Den Bergen JA, Ohnesorg T, Eggers S, Hanna C, Hersmus R, Thompson EM, Baxendale A, Verge CF, Lafferty AR et al. 2018 Functional characterization of novel NR5A1 variants reveals multiple complex roles in disorders of sex development. Human Mutation 39 124-139. (https://doi.org/10.1002/humu.23354)

Sala C, Arrigo G, Torri G, Martinazzi F, Riva P, Larizza L, Philippe C, Jonveaux P, Sloan F, Labella T et al. 1997 Eleven X chromosome breakpoints associated with premature ovarian failure (POF) map to a 15-Mb YAC contig spanning Xq21. Genomics 40 123-131. (https://doi. org/10.1006/geno.1996.4542)

Santos MG, Machado AZ, Martins CN, Domenice S, Costa EM, Nishi MY, Ferraz-De-Souza B, Jorge SA, Pereira CA, Soardi FC et al. 2014 Homozygous inactivating mutation in NANOS3 in two sisters with primary ovarian insufficiency. BioMed Research International 2014 787465. (https://doi.org/10.1155/2014/787465)

Schlessinger D, Herrera L, Crisponi L, Mumm S, Percesepe A, Pellegrini M, Pilia G \& Forabosco A 2002 Genes and translocations involved in POF. American Journal of Medical Genetics 111 328-333. (https://doi. org/10.1002/ajmg.10565)

Sherman SL 2000 Premature ovarian failure in the fragile $X$ syndrome. American Journal of Medical Genetics 97 189-194. (https://doi.org/10.1002/1096-8628(200023)97:3<189::AIDAJMG1036>3.0.CO;2-J)

Singh RP \& Carr DH 1966 The anatomy and histology of XO human embryos and fetuses. Anatomical Record 155 369-383. (https://doi. org/10.1002/ar.1091550309)

Smirin-Yosef P, Zuckerman-Levin N, Tzur S, Granot Y, Cohen L, Sachsenweger J, Borck G, Lagovsky I, Salmon-Divon M, Wiesmüller L et al. 2017 A biallelic mutation in the homologous recombination repair gene SPIDR is associated with human gonadal dysgenesis. Journal of Clinical Endocrinology and Metabolism 102 681-688. (https://doi. org/10.1210/jc.2016-2714)

Stolk L, Perry JR, Chasman DI, He C, Mangino M, Sulem P, Barbalic M, Broer L, Byrne EM, Ernst F et al. 2012 Meta-analyses identify 13 loci associated with age at menopause and highlight DNA repair and immune pathways. Nature Genetics 44 260-268. (https://doi.org/10.1038/ ng.1051)

Summitt RL, Tipton RE, Wilroy Jr RS, Martens PR \& Phelan JP 1978 $X$-autosome translocations: a review. Birth Defects Original Article Series 14 219-247.

Therman E, Laxova R \& Susman B 1990 The critical region on the human Xq. Human Genetics 85 455-461. (https://doi.org/10.1007/BF00194216)

Toniolo D \& Rizzolio F 2007 X chromosome and ovarian failure. Seminars in Reproductive Medicine 25 264-271. (https://doi. org/10.1055/s-2007-980220)

Tosh D, Rani HS, Murty US, Deenadayal A \& Grover P 2015 Mutational analysis of the FIGLA gene in women with idiopathic premature ovarian failure. Menopause 22 520-526. (https://doi.org/10.1097/ GME.0000000000000340)

Van Kasteren YM \& Schoemaker J 1999 Premature ovarian failure: a systematic review on therapeutic interventions to restore ovarian function and achieve pregnancy. Human Reproduction Update 5 483-492. (https://doi.org/10.1093/humupd/5.5.483)

Villanueva AL \& Rebar RW 1983 Triple-X syndrome and premature ovarian failure. Obstetrics and Gynecology 62 (Supplement) 70s-73s.

Visser JA, Schipper I, Laven JS \& Themmen AP 2012 Anti-Mullerian hormone: an ovarian reserve marker in primary ovarian insufficiency. Nature Reviews: Endocrinology 8 331-341. (https://doi.org/10.1038/ nrendo.2011.224) 
Wang H, Li G, Zhang J, Gao F, Li W, Qin Y \& Chen ZJ 2015 Novel WT1 missense mutations in Han Chinese women with premature ovarian failure. Scientific Reports 5 13983. (https://doi.org/10.1038/srep13983)

Wang B, Li L, Zhu Y, Zhang W, Wang X, Chen B, Li T, Pan H, Wang J, Kee K et al. 2017 Sequence variants of KHDRBS1 as high penetrance susceptibility risks for primary ovarian insufficiency by mis-regulating mRNA alternative splicing. Human Reproduction 32 2138-2146. (https://doi.org/10.1093/humrep/dex263)

Wang Q, Li D, Cai B, Chen Q, Li C, Wu Y, Jin L, Wang X, Zhang X \& Zhang F 2019 Whole-exome sequencing reveals SALL4 variants in premature ovarian insufficiency: an update on genotype-phenotype correlations. Human Genetics 138 83-92. (https://doi.org/10.1007/ s00439-018-1962-4)

Weinberg-Shukron A, Renbaum P, Kalifa R, Zeligson S, Ben-Neriah Z, Dreifuss A, Abu-Rayyan A, Maatuk N, Fardian N, Rekler D et al. 2015 A mutation in the nucleoporin-107 gene causes XX gonadal dysgenesis. Journal of Clinical Investigation 125 4295-4304. (https://doi. org/10.1172/JCl83553)

Welt CK 2008 Primary ovarian insufficiency: a more accurate term for premature ovarian failure. Clinical Endocrinology 68 499-509. (https:// doi.org/10.1111/j.1365-2265.2007.03073.x)

Woad KJ, Watkins WJ, Prendergast D \& Shelling AN 2006 The genetic basis of premature ovarian failure. Australian and New Zealand Journal of Obstetrics and Gynaecology 46 242-244. (https://doi.org/10.1111/ j.1479-828X.2006.00585.x)

Wood-Trageser MA, Gurbuz F, Yatsenko SA, Jeffries EP, Kotan LD, Surti U, Ketterer DM, Matic J, Chipkin J, Jiang H et al. 2014 MCM9 mutations are associated with ovarian failure, short stature, and chromosomal instability. American Journal of Human Genetics 95 754-762. (https:// doi.org/10.1016/j.ajhg.2014.11.002)

Yang L, Li T \& Xing Y 2017 Identification of a novel FOXL2 mutation in a single family with both types of blepharophimosis-ptosis-epicanthus inversus syndrome. Molecular Medicine Reports 16 5529-5532. (https:// doi.org/10.3892/mmr.2017.7226)

Yatsenko SA \& Rajkovic A 2019 Genetics of human female infertilitydagger. Biology of Reproduction 101 549-566. (https://doi.org/10.1093/biolre/ ioz084)

Zangen D, Kaufman Y, Zeligson S, Perlberg S, Fridman H, Kanaan M, Abdulhadi-Atwan M, Abu Libdeh A, Gussow A, Kisslov I et al. 2011 XX ovarian dysgenesis is caused by a PSMC3IP/HOP2 mutation that abolishes coactivation of estrogen-driven transcription. American Journal of Human Genetics 89 572-579. (https://doi.org/10.1016/j. ajhg.2011.09.006)

Zepeda-Mendoza CJ, Ibn-Salem J, Kammin T, Harris DJ, Rita D, Gripp KW, Mackenzie JJ, Gropman A, Graham B, Shaheen R et al. 2017 Computational prediction of position effects of apparently balanced human chromosomal rearrangements. American Journal of Human Genetics 101 206-217. (https://doi.org/10.1016/j.ajhg.2017.06.011)

Zhao M, Feng F, Chu C, Yue W \& Li L 2019 A novel EIF4ENIF1 mutation associated with a diminished ovarian reserve and premature ovarian insufficiency identified by whole-exome sequencing. Journal of Ovarian Research 12 119. (https://doi.org/10.1186/s13048-019-0595-0)

Zhe J, Chen S, Chen X, Liu Y, Li Y, Zhou X \& Zhang J 2019 A novel heterozygous splice-altering mutation in HFM1 may be a cause of premature ovarian insufficiency. Journal of Ovarian Research 1261. (https://doi.org/10.1186/s13048-019-0537-x)

Received 6 March 2020

First decision 11 May 2020

Revised manuscript received 17 June 2020

Accepted 3 August 2020 